\title{
Pengaruh Pijat Oksitosin terhadap Produksi ASI pada Ibu Post Sectio Cesarea
}

\author{
Susianti ${ }^{*}$, Arifa Usman \\ STIKES Mega Buana Palopo \\ *Email korespondensi: susianti.asry@gmail.com
}

\section{Article Info}

Article history:

Submitted:2019-10-31

Accepted:2019-12-26

Published: 2019-12-30

Keywords:

Oksitosin Massage; Breastfeeding; Post Sectio Secarea.

\section{ABSTRACT}

Oxytocin massage is performed to stimulate the oxytocin reflex or let down reflex. By doing this massage, the mother will feel relaxed, so that the hormone oxytocin comes out the breast milk quickly. The purpose of this study was to determine the effect of oxytocin massage on breast milk production in post sectio secarea mothers. This research method used a quasi-experimental method (Quasi Experiment) with Post Test Only design with control group design. The sampling technique with non-probability sampling was consecutive sampling with the number of respondents as many as 50 samples, namely 25 samples for the intervention group and 25 people with the control group. Data analysis applied the Chi-Square test. The results of the bivariate analysis showed that the $p$-value in each measurement was $0.039,0.003,0.002$, which means that there were differences in the proportions of the smoothness of breast milk in the intervention group and the control group. Conclusion: There is a difference in the proportion of smoothness of breast milk in the intervention group and the control group, and there is no relationship between oxytocin massage with age, education, occupation, and parity.

\section{ABSTRAK}

\section{Kata Kunci:}

Pijat Oksitosin; AS; Post SC.
Pijat oksitosin dilakukan untuk merangsang refleks oksitosin atau refleks let down. Dengan dilakukan pemijatan ini ibu akan merasa rileks, sehingga dengan begitu hormon oksitosin keluar ASI pun cepat keluar. Tujuan penelitian ini Diketahuinya pengaruh Pijat Oksitosin terhadap produksi ASI pada ibu post sectio secarea. Metode penelitian ini menggunakan metode eksperimen semu (Quasi Eksperimen) dengan rancangan post test only design with control group. Teknik pengambilan sampel dengan non probability sampling yaitu Consecutive Sampling dengan jumlah responden sebanyak 50 sampel yaitu sebanyak 25 sampel untuk kelompok intervensi dan 25 orang dengan kelompok kontrol. Analisis data menggunakan uji Chi-Square. Hasil analisis bivariat didapatkan nilai $p$ pada masing-masing pengukuran adalah $0,039,0,003,0,002$ yang berarti ada perbedaan proporsi kelancaran ASI pada kelompok intervensi dan kelompok kontrol. Kesimpulan: Ada perbedaan proporsi kelancaran ASI pada kelompok intervensi dan kelompok kontrol dan tidak ada hubungan antara pijat oksitosin dengan Umur, Pendidikan, Pekerjaan dan Paritas. 


\section{PENDAHULUAN}

Air Susu Ibu (ASI) merupakan makanan yang terbaik dan yang paling ideal untuk bayi, karena ASI mengandung semua zat gizi yang diperlukan dalam jumlah dan pertimbangan yang tepat. Menyusui adalah metode yang tepat untuk memberikan makanan pada bayi karena memberikan manfaat kesehatan untuk ibu dan bayi yang tergantung pada gabungan kerja hormon, refleks dan perilaku yang dipelajari ibu dan bayi baru lahir yang terjadi secara alami. ${ }^{1-3}$

Ibu yang menjalani bedah caesar mungkin belum mengeluarkan ASI nya dalam 24 jam pertama setelah melahirkan, kadangkala perlu waktu hingga 48 jam walaupun demikian bayi tetap dianjurkan untuk dilekatkan pada payudara ibu untuk membantu merangsang pengeluaran ASI pertama. ${ }^{4}$ Keterlambatan pengeluaran ASI pada ibu sectio caesar disebabkan karena timbulnya nyeri post partum yang secara fisiologis dapat menghambat pengeluaran hormon oksitosin yang sangat berperan dalam proses laktasi.

Pencapaian ASI Eksklusif di Indonesia belum mencapai 80\%. Berdasarkan laporan SDKI tahun 2013 pencapaian ASI eksklusif adalah 42\%. Sedangkan, Menurut Riset Kesehatan Dasar (Riskesdas) tahun 2013, cakupan pemberian ASI Eksklusif pada bayi usia 0-6 bulan di Propinsi Sulawesi Selatan yaitu 71.5 persen artinya cakupan pemberian ASI Eksklusif pada bayi usia kurang dari enam bulan Propinsi Sulawesi Selatan telah mencapai target (Kemenkes, 2013) dan hampir mencapai level tertinggi target cakupan ASI Eksklusif tahun 2019 yaitu sebesar 80 persen (Bappenas, 2014). Dan Cakupan pemberian ASI eksklusif di Parepare hanya $35,3 \%$.

Salah satu faktor yang dapat meningkatkan produksi ASI adalah Pijat oksitosin, dimana pijat oksitosin merupakan tindakan untuk merangsang hipofisis anterior dan posterior sehingga mengeluarkan hormon oksitosin. Pijat oksitosin adalah pemijatan sepanjang tulang belakang (vertebrae) merupakan usaha untuk merangsang hormon oksitosin setelah melahirkan. ${ }^{5}$

Pijat oksitosin dilakukan untuk merangsang refleks oksitosin atau refleks letdown. Dengan dilakukan pemijatan ini ibu akan merasa rileks, kelelahan setelah melahirkan akan hilang, sehingga dengan begitu hormon oksitosin keluar ASI pun cepat keluar. ${ }^{6}$ Selain untuk merangsang refleks let down manfaat pijat oksitosin adalah memberikan kenyamanan pada ibu, mengurangi bengkak (engorgement), mengurangi sumbatan ASI, merangsang pelepasan hormon oksitosin, mempertahankan produksi ASI ketika ibu dan bayi sakit. ${ }^{7}$ Saat ini belum banyak tenaga kesehatan yang menggunakan metode pijat oksitosin untuk peningkatan produksi ASI. sehingga perlu dilakukan penelitian lebih lanjut. Tujuan penelitian ini adalah untuk mengetahui pengaruh pijat oksitosin terhadap produksi ASI pada ibu post sectio cesarea

\section{METODE PENELITIAN}

Penelitian ini dibagi menjadi beberapa tahapan. Tahap awal penelitian ini dimulai dengan membagi dua kelompok perlakuan dan kelompok kontrol. Tahapan selanjutnya salah satu kelompok yang sudah di tentukan akan mendapatkan treatment yaitu Pijat Oksitosin. Setelah itu setiap kelompok akan dinilai produksi ASInya.

Metode penelitian ini menggunakan metode eksperimen semu (quasi eksperimen) dengan rancangan post test only design with control group. Teknik pengambilan sampel dengan non probability sampling yaitu consecutive Sampling. 
Penelitian ini melihat produksi ASI pada kelompok intervensi maupun kelompok kontrol yaitu dengan cara melakukan pijat oksitosin kepada kelompok intervensi sebanyak 4 kali yaitu pada hari ke II dan ke III dilakukan masing-masing pagi dan sore hari pada ibu post sectio cesarea. Produksi ASI dikatakan lancar jika berat badan bayi tetap atau bertambah, frekuensi BAK 6-8 kali/hari, frekuensi menyusui 8-12 kali/hari dan bayi tidur nyenyak 2-3 jam setelah menyusui. Teknik pengumpulan data dilakukan dengan lembar observasi untuk mengetahui produksi ASI. Jumlah subjek dalam penelitian ini adalah 25 responden kelompok intrevensi dan 25 responden untuk kelompok kontrol. untuk menentukan besaran sampel menggunakan rumus uji hipotesis beda proporsi. Uji statistik menggunakan uji Chi Square

\section{HASIL PENELITIAN}

Berdasarkan penelitian yang telah dilaksanakan maka diperoleh hasil sebagai berikut:

\section{Karakteristik Responden}

Tabel 1 Distribusi Responden berdasarkan Umur, Pendidikan, Pekerjaan, dan Paritas pada Kelompok Intervensi dan Kontrol di RSU Andi Makkasau Parepare

\begin{tabular}{llcccc}
\hline \multirow{2}{*}{ Variabel } & Kategori & Intervensi & $\begin{array}{c}\text { Presentase } \\
\text { \% }\end{array}$ & Kontrol & $\begin{array}{c}\text { Presentase } \\
\%\end{array}$ \\
\cline { 3 - 6 } & & & 60 & 15 & 60 \\
\hline \multirow{4}{*}{ Umur } & $<$ 30 Tahun & 15 & 40 & 10 & 40 \\
\multirow{5}{*}{ Pekndidikan } & $\geq$ 30 Tahun & 10 & 36 & 12 & 48 \\
& Rendah & 9 & 64 & 13 & 52 \\
Paritas & Tinggi & 16 & 32 & 5 & 20 \\
& Bekerja & 8 & 68 & 20 & 80 \\
& Tidak Bekerja & 17 & 48 & 7 & 28 \\
& Primipara & 12 & 52 & 18 & 72 \\
\hline
\end{tabular}

Dari tabel 1 dapat diketahui bahwa pada kebanyakan ibu memiliki umur $<30$ tahun dari kelompok intervensi sebanyak $15(60 \%)$ dan dari kelompok Kontrol yaitu 15 $(60 \%)$. Berdasarkan Pendidikan dari kelompok intervensi sebagian besar dengan pendidikan tinggi yaitu $16(64 \%)$ sedangkan pada kelompok kontrol dengan pendidikan tinggi yaitu $13(52 \%)$. Berdasarkan pekerjaan sebagian besar tidak bekerja dari kelompok intervensi yaitu sebanyak 17 (68\%) begitupun dengan kelompok kontrol yaitu sebanyak $20(80 \%)$. Berdasarkan paritas dari kelompok intervensi multipara sebanyak 13 (52\%) dan dari kelompok kontrol sebagian besar multipara yaitu $18(72 \%)$.

2. Perbedaan Produksi ASI pada Kelompok Intervensi dan Kelompok Kontrol pada Pengukuran Pertama, Kedua, dan Ketiga 
Tabel 2 Distribusi Ibu Post Sectio Cesarea Menurut Produksi ASI pada Kelompok Intervensi dan Kelompok Kontrol Pada Pengukuran I, II, dan III di RSU Andi Makkasau Parepare

\begin{tabular}{|c|c|c|c|c|c|c|c|}
\hline \multirow[b]{2}{*}{ Pengukuran } & \multicolumn{6}{|c|}{ Produksi ASI } & \multirow{2}{*}{ Nilai $p$} \\
\hline & Kelompok & Lancar & $\%$ & $\begin{array}{c}\text { Tidak } \\
\text { Lancar }\end{array}$ & $\%$ & OR $95 \% \mathrm{Cl}$ & \\
\hline \multirow{2}{*}{ I } & Intervensi & 13 & 52 & 12 & 48 & 1,6 & 0,039 \\
\hline & Kontrol & 5 & 20 & 20 & 80 & $(1,1-2,5)$ & \\
\hline \multirow{2}{*}{ II } & Intervensi & 17 & 68 & 8 & 32 & 2,8 & 0,003 \\
\hline & Kontrol & 11 & 44 & 14 & 56 & $(1,5-5,4)$ & \\
\hline \multirow{2}{*}{ III } & Intervensi & 18 & 72 & 7 & 28 & 3,6 & 0,002 \\
\hline & Kontrol & 13 & 52 & 12 & 48 & $(1,7-7,6)$ & \\
\hline
\end{tabular}

Berdasarkan hasil analisis pengaruh pijat oksitosin terhadap produksi ASI pada post Sectio Cesarea, pada pengukuran Pertama didapatkan hasil sebanyak $13(52 \%)$ yang telah diberikan intervensi Pijat oksitosin yang produksi ASInya lancar. Sedangkan pada kelompok kontrol ibu post sectio yang produksi ASInya lancar sebanyak 5 orang (20\%). Berdasarkan hasil uji statistik nilai $p=0,039$ yang artinya ada perbedaan proporsi kelancaran ASI pada kelompok kontrol dan kelompok intervensi. Berdasarkan hasil analisis juga diperoleh nilai $\mathrm{OR}=1,6$ yang artinya ibu yang di berikan intervensi pijat oksitosin mempunyai peluang 1,6 kali lebih besar produksi Asinya lancar dibandingkan dengan kelompok kontrol.

Pada pengukuran kedua ibu dengan post sectio cesarea yang produksi ASI nya lancar mengalami peningkatan yaitu 17 orang (68\%) sedangkan pada kelompok kontrol sebanyak 11 orang (44\%) yang produksi ASInya lancar. Berdasarkan hasil uji statistik di peroleh nilai $p=0,003$ yang artinya ada perbedaan proporsi kelancaran ASI pada kelompok kontrol dan kelompok intervensi. Serta dari hasil uji analisis di dapatkan nilai $O R=2,8$ yang artinya ibu Post Sectio Cesarea yang di berikan intervensi Pijat oksitosin mempunyai peluang 2,8 kali lebih besar dengan produksi ASI lancar di bandingkan dengan kelompok kontrol.

Pada pengukuran yang ketiga ibu yang produksi ASInya lancar sebanyak 18 orang (72\%) pada kelompok intervensi sedangkan pada kelompok kontrol hanya sebanyak 13 orang $(52 \%)$. Dari hasil uji statistik di dapatkan hasil dengan nilai $p=0,002$ yang berarti bahwa ada perbedaan kelancaran ASI pada kelompok intervensi dan kelompok kontrol. Serta dari hasil analisis di dapatkan nilai $\mathrm{OR}=3,6$ yang artinya bahwa ibu dengan intervensi pijat oksitosin mempunyai peluang 3 kali lebih berpeluang ASInya lancar di bandingkan dengan kelompok yang tidak di berikan intervensi atau kelompok kontrol.

Berdasarkan hasil analisis menunjukan bahwa ibu dengan post sectio secarea yang produksi ASInya lancar terus meningkat dari pengukuran pertama, pengukuran kedua dan pengukuran ketiga pada kelompok intervensi sedangkan pada kelompok kontrol sebaliknya. 
a. Pengaruh Karakteristik Umur, Pendidikan, Pekerjaan, dan Paritas terhadap Produksi ASI pada Kelompok Intervensi

Tabel 3 Distribusi Ibu Post SC Menurut Umur, Pendidikan, Pekerjaan dan Paritas terhadap Produksi ASI Pada Kelompok Intervensi di RSU Andi Makkasau Parepare

\begin{tabular}{|c|c|c|c|c|c|c|}
\hline \multirow{3}{*}{ Variabel } & \multirow{3}{*}{ Kategori } & \multicolumn{4}{|c|}{ Produksi ASI } & \multirow{3}{*}{ Nilai $p$} \\
\hline & & \multicolumn{2}{|c|}{ Lancar } & \multicolumn{2}{|c|}{ Tidak Lancar } & \\
\hline & & $\mathrm{N}$ & $\%$ & $\mathrm{n}$ & $\%$ & \\
\hline \multirow{2}{*}{ Umur } & $<30$ Thn & 12 & 80,0 & 3 & 20,0 & \multirow[t]{2}{*}{0,378} \\
\hline & $\geq 30$ Thn & 6 & 60,0 & 4 & 40,0 & \\
\hline \multirow{3}{*}{ Pendidikan } & Rendah & 8 & 88,9 & 1 & 11,1 & \multirow[t]{2}{*}{0,355} \\
\hline & Tinggi & 10 & 62,5 & 6 & 37,5 & \\
\hline & Bekerja & 6 & 75,0 & 2 & 25,0 & \multirow{2}{*}{1,000} \\
\hline Pekerjaan & $\begin{array}{l}\text { Tidak } \\
\text { Bekeria }\end{array}$ & 12 & 70,6 & 5 & 29,4 & \\
\hline \multirow{2}{*}{ Paritas } & Primipara & 8 & 66,7 & 4 & 33,3 & \multirow[t]{2}{*}{0,673} \\
\hline & Multipara & 10 & 76,9 & 3 & 23,1 & \\
\hline
\end{tabular}

Berdasarkan tabel 3 menunjukan bahwa ibu post sectio cesarea yang produksi ASInya lancar kebanyakan dengan kriteria umur $<30$ tahun yaitu sebanyak 12 orang ( $80 \%$ ) sedangkan dengan kriteria umur $>30$ tahun yaitu sebanyak 6 orang $(60 \%)$.

Berdasarkan kriteria pendidikan ibu dengan Post Sectio cesarea yang asinya lancar lebih banyak pada ibu dengan pendidikan tinggi yaitu sebanyak 10 orang $(62,5 \%)$ sedangkan ibu post sectio cesarea dengan kategori pendidikan rendah sebanyak 8 orang $(88,9 \%)$.

Dari variabel pekerjaan kebanyakan ibu yang ASInya lancar yaitu dari ibu yang tidak bekerja yaitu sebanyak 12 orang $(70,6 \%)$ sedangkan ibu yang bekerja dan ASInya lancar hanya sebanyak 6 orang $(75 \%)$.

Berdasarkan variabel paritas ibu dengan sectio cesarea pada kriteria multipara yang ASI nya lancar sebanyak 10 orang $(76,9)$ sedangkan ibu post sectio cesarea primipara yang ASInya lancar sebanyak 8 orang $(66,7 \%)$.

b. Pengaruh Karakteristik Umur, Pendidikan, Pekerjaan dan Paritas terhadap Produksi ASI Pada Kelompok Kontrol

Tabel 4 Distribusi Ibu Post SC Menurut Umur, Pendidikan, Pekerjaan, dan Paritas terhadap Produksi ASI Pada Kelompok Kontrol di RSU Andi Makkasau Parepare

\begin{tabular}{|c|c|c|c|c|c|c|}
\hline \multirow{3}{*}{ Variabel } & \multirow{3}{*}{ Kategori } & \multicolumn{4}{|c|}{ Produksi ASI } & \multirow{3}{*}{ Nilai $p$} \\
\hline & & \multicolumn{2}{|c|}{ Lancar } & \multicolumn{2}{|c|}{ Tidak Lancar } & \\
\hline & & $\mathrm{N}$ & $\%$ & $n$ & $\%$ & \\
\hline \multirow{2}{*}{ Umur } & $<30$ Thn & 7 & 46,7 & 8 & 53,3 & \multirow{2}{*}{1,000} \\
\hline & $\geq 30$ Thn & 5 & 50,0 & 5 & 50,0 & \\
\hline \multirow{3}{*}{ Pendidikan } & Rendah & 5 & 41,7 & 7 & 58,3 & \multirow[t]{2}{*}{0,434} \\
\hline & Tinggi & 8 & 61,5 & 5 & 38,5 & \\
\hline & Bekerja & 2 & 40,0 & 3 & 60,0 & \multirow{2}{*}{0,645} \\
\hline Pekerjaan & $\begin{array}{l}\text { Tidak } \\
\text { Bekeria }\end{array}$ & 11 & 55,0 & 9 & 45,0 & \\
\hline \multirow{2}{*}{ Paritas } & Primipara & 5 & 71,4 & 2 & 28,6 & \multirow[t]{2}{*}{0,378} \\
\hline & Multipara & 8 & 44,4 & 10 & 55,6 & \\
\hline
\end{tabular}


Berdasarkan hasil tabel 4 menunjukan bahwa ibu post sectio cesarea yang berumur $<30$ tahun yang produksi ASInya tidak lancar sebanyak 8 orang $(53,3 \%)$ sedangkan ibu dengan post sectio cesarea dengan umur $>30$ tahun yang ASInya tidak lancar sebanyak 5 orang (50\%).

Berdasarkan karakteristik pendidikan ibu post sectio secarea yang berpendidikan rendah mempunyai produksi ASI yang tidak lancar yaitu sebanyak 7 orang $(58,3 \%)$ dan yang berpendidikan tinggi yang ASInya tidak lancar sebanyak 5 orang $(38,5 \%)$.

Berdasarkan karakteristik pekerjaan ibu post sectio secarea yang tidak bekerja mempunyai produksi ASI yang tidak lancar yaitu sebanyak 9 orang $(45 \%)$ dan yang berpendidikan tinggi yang ASInya tidak lancar sebanyak 3 orang $(60 \%)$.

Pada tabel karakteristik paritas ibu post sectio secarea yang multipara mempunyai produksi ASI yang tidak lancar yaitu sebanyak 10 orang (55,6\%) dan yang primipara yang ASInya tidak lancar sebanyak 2 orang $(28,6 \%)$.

\section{PEMBAHASAN}

Dari hasil penelitian menunjukan bahwa ibu dengan post sectio secarea yang produksi ASInya lancar pada kelompok yang diberikan intervensi berupa pijat oksitosin jumlahnya lebih besar di bandingkan dengan produksi ASI yang tidak lancar dan dari hasil analisis didapatkan nilai $p=0,002$ pada pengukuran terakhir yang menunjukan bahwa ada perbedaan produksi ASI antara kelompok intervensi dan kelompok kontrol. Sedangkan nilai $\mathrm{OR}=3,6$ yang berarti bahwa ibu yang di berikan intervensi berupa pijat oksitosin berpeluang 3,6 kali lebih besar produksi ASInya lancar dibandingkan dengan kelompok kontrol. Hal ini menjelaskan bahwa hipotesis peneliti terbukti ibu post sectio secarea yang diberikan intervensi pijat oksitosin dapat mempengaruhi produksi ASI.

Hasil penelitian ini diperkuat dengan penelitian yang dilakukan oleh Siti Nur Endah dan Imas Masdinarsah (2011) didapatkan bahwa jumlah Kolostrum yang dikeluarkan oleh ibu post partum yang dilakukan pijat oksitosin (Perlakuan) adalah rata-rata 5,333 cc sedangkan jumlah Kolostrum yang dikeluarkan oleh ibu post partum yang tidak dilakukan pijat oksitosin (kontrol) adalah rata-rata 0,0289 $\mathrm{cc}^{8}$ Penelitian Muliani et al, diperoleh hasil bahwa kombinasi perawatan payudara dan pijat oksitosin lebih efektif terhadap jumlah produksi ASI 1,26 cc lebih banyak dibanding pada ibu yang hanya mendapatkan perawatan payudara. ${ }^{9}$

Beberapa hal yang ditemukan di lapangan pada saat proses penelitian didapatkan bahwa produksi ASI yang sedikit pada 3 hari pertama setelah melahirkan menjadi kendala pemberian ASI secara dini. Produksi ASI pada awal setelah melahirkan dapat ditingkatkan dengan memberikan rangsangan prolaktin dan oksitosin untuk kelancaran produksi ASI. Kondisi lain yang juga dialami oleh ibu yang melahirkan melalui proses sectio secarea adalah dalam 24 jam pertama setelah kelahiran bayi ibu belum dianjurkan untuk duduk serta kondisi luka bekas sectio secarea menyebabkan ibu terbatas untuk miring. Sementara rangsangan hisapan bayi pada awal kelahiran bayi juga dapat menyebabkan produksi ASI lebih cepat. Hal ini juga yang menjadi kendala pada ibu yang melahirkan dengan sectio secarea dalam produksi ASI adalah karena penggunaan obat-obatan.

Pengaruh pijat oksitosin terhadap produksi ASI jika di lihat dari hasil analisis berdasarkan kriteria umur, pendidikan, pekerjaan dan paritas yang tidak berpengaruh terhadap kelancaran ASI Ibu. Teknik pijat oksitosin jika dapat dilakukan oleh ibu pada 
saat awal setelah kelahiran bayi maka masalah yang sering muncul seperti ASI kurang dan ASI tidak lancar dapat teratasi dan mengurangi penggunaan susu formula pada ibu dengan sectio secarea serta dapat meningkatkan cakupan ASI Ekslusif.

Berdasarkan tabel 2 dapat di lihat bahwa ibu yang ASInya lancar kebanyakan dengan umur $<30$ tahun yaitu sebanyak 12 orang sementara ibu dengan kriteria umur $>30$ tahun hanya 6 orang. Hal ini menunjukan bahwa ibu dengan umur yang lebih muda akan lebih banyak memproduksi ASI dibandingkan dengan ibu yang umurnya lebih tua. Hal ini sesuai dengan pendapat Pudjiadi (2005) mengatakan bahwa ibu yang berumur 19-23 tahun pada umumnya dapat menghasilkan ASI yang cukup di bandingkan dengan ibu yang berumur $>30$ tahun. ${ }^{10}$ Juga pendapat Suraatmaja (2001) menyatakan bahwa ibu yang berumur lebih muda mempunyai produksi ASI yang lebih lancar di bandingkan dengan ibu yang berumur lebih tua. ${ }^{11}$

Kriteria pendidikan antara ibu dengan pendidikan tinggi dan pendidikan rendah hanya terdapat selisih 2 orang yaitu ibu dengan pendidikan tinggi yang ASInya lancar sebanyak 10 orang sedangkan ibu dengan pendidikan rendah yang Asinya lancar yaitu 8 orang. Penelitian yang dilakukan oleh Moore dan Coty (2006) menyatakan bahwa keberhasilan menyusui tidak ditentukan dari tingkat pendidikan ibu akan tetapi informasi yang diterima ibu tentang menyusui pada saat kehamilan. ${ }^{12} \mathrm{lbu}$ post partum ternyata membutuhkan informasi tentang menyusui pada saat kehamilan dan informasi yang diterima harus konsisten dan realistis. Pada hasil penelitian juga menunjukan bahwa tidak terdapat hubungan antara pendidikan dan produksi ASI. Ibu dengan pendidikan rendah pun dapat berhasil memberikan ASI eksklusif jika mendapatkan informasi yang benar tentang proses menyusui sebelumnya. Sehingga Informasi yang di terima pada saat masa kehamilan menjadi suatu hal yang sangat penting dalam hal ini.

Dari hasil penelitian dapat di lihat bahwa ibu yang tidak bekerja lebih banyak yang ASInya lancar dibandingkan dengan ibu yang bekerja. Yaitu terdapat 12 orang yang Asinya lancar pada ibu tidak tidak bekerja dan 6 orang pada ibu yang bekerja. Ibu bekerja ternyata mempengaruhi produksi ASI walaupun sebelumnya sudah di jelaskan tentang teknik menyusui. ${ }^{13}$. Menurut Roesli bekerja bukan merupakan alasan untuk menghentikan ASI eksklusif, meskipun cuti melahirkan hanya 3 bulan. Dengan pengetahuan yang benar tentang menyusui dan perlengkapan memerah ASI, seorang ibu yang bekerja pun dapat tetap memberikan ASI secara eksklusif. ${ }^{14,15}$

Ibu dengan kategori multipara mempunyai proporsi produksi ASI lancar lebih banyak dibandingkan dengan ibu dengan kategori Primipara. Hal ini sesuai dengan penelitian Lovelady (2005) menyatakan bahwa ibu multipara menunjukan produksi ASI lebih lancar di bandingkan dengan ibu dengan kategori Primipara. ${ }^{16}$ Pengalaman dan keyakinan ibu pada saat menyusui sebelumnya akan mempengaruhi perilaku ibu pada saat proses menyusui selanjutnya. Jika ibu berhasil menyusui pada saat anak pertama maka pada saat menyusui anak kedua ibu lebih yakin dapat berhasil untuk menyusui. Keyakinan ibu ini dapat merangsang pengeluaran hormon oksitosin sehingga ASI dapat keluar lebih lancar.

\section{SIMPULAN DAN SARAN}

Hasil analisis bivariat diperoleh nilai $p$ pada masing-masing pengukuran adalah $0,03,0,003$ dan 0,002 yang berarti ada perbedaan proporsi kelancaran ASI antara kelompok intervensi dan kelompok kontrol dengan nilai OR pada pengukuran terakhir sebesar 3,600 yang berarti ibu post SC yang di berikan pijat oksitosin berpeluang 3,6 kali lebih besar untuk mempunyai produksi ASI lebih lancar dibandingkan kelompok 
kontrol. Hasil analisis statistik menunjukkan tidak ada pengaruh karakteristik responden terhadap produksi ASI pada kelompok intervensi maupun kelompok kontrol. Penelitian ini menyarankan pihak rumah sakit peneliti untuk dapat menggunakan pijat oksitosin sebagai bentuk intervensi untuk meningkatkan produksi ASI pada ibu Post SC. Perlu dilakukan penelitian lanjutan antara intervensi pijat oksitosin dengan intervensi lain seperti breast care, menyusu dini untuk meningkatkan produksi ASI pada ibu post SC. Perlu dilakukan pelatihan tentang pijat oksitosin kepada perawat dan bidan agar mereka mampu menerapkan dan mengajarkan pada ibu post SC.

\section{UCAPAN TERIMA KASIH}

Penelitian menyampaikan terima kasih kepada Kementerian Riset, Teknologi, dan Pendidikan Tinggi melalui Kopertis Wilayah IX yang telah memberikan bantuan dana, Dr. Hj. Nilawati Uly selaku Ketua Stikes Mega Buana Palopo yang memberikan dukungan kepada para dosen untuk selalu meneliti, Resty Ryadinency, S.Gz.,M.Gizi selaku Ketua LPPM Stikes Mega Buana Palopo yang selalu memberikan informasi, dr. Renny Anggraeni Sary, M.Kes selaku Direktur RSU Andi Makkasau Parepare yang telah memberikan izin kepada peneliti, Ibu post sectio secarea yang telah bersedia menjadi responden dalam penelitian ini.

\section{DAFTAR PUSTAKA}

1. Poedianto DH. Seri Ayahbunda: Kiat Sukses Menyusui. Jakarta: Aspirasi Pemuda; 2002.

2. Bobak IM, Lowdermilk DL, Jensen MD. Buku Ajar Keperawatan Maternitas. 4th ed. Jakarta: EGC; 2005.

3. Pillitteri A. Maternal \& child health nursing: care of the childbearing \& childrearing family. 6th ed. Philadelphia: Wolters Kluwer Health/Lippincott Williams \& Wilkins; 2010. 1778 p.

4. Dewey KG, Nommsen-Rivers LA, Heinig MJ, Cohen RJ. Risk Factors for Suboptimal Infant Breastfeeding Behavior, Delayed Onset of Lactation, and Excess Neonatal Weight Loss. PEDIATRICS [Internet]. 2003 Sep 1 [cited 2019 Dec 25];112(3):607-19. Available from: http://pediatrics.aappublications.org/cgi/doi/10.1542/peds.112.3.607

5. Biancuzzo M. Breastfeeding the Newborn: Clinical Strategies for Nurses. 2nd ed. Elsevier Health Sciences; 2002.

6. Mardiyaningsih E, Setyowati, Sabri L. Efektifitas Kombinasi Teknik Marmet Dan Pijat Oksitosin terhadap Produksi Asi lbu Post Seksio di Rumah Sakit Wilayah Jawa Tengah. J Keperawatan Soedirman. 2011;6(1):31-8.

7. Departemen Kesehatan R.I. Pelatihan Konseling Menyusui. Jakarta: Departemen Kesehatan R.I; 2007.

8. Endah SN, Masdinarsah I. Pengaruh Pijat Oksitosin terhadap Pengeluaran Kolostrum pada Ibu Postpartum. J Kesehat Kartika [Internet]. 2011;1-9. Available from: http://www.stikesayani.ac.id/publikasi/e-journal/filesx/2011/201112/201112-001.pdf

9. Muliani M, Arsyad G, Nurlaila Dilla T. Efektifitas Kombinasi Perawatan Payudara dan Pijat Oksitosin terhadap Produksi ASI pada Ibu Post Partum di BPM Setia. Poltekita J IImu Kesehat [Internet]. 2018 Oct 7 [cited 2019 Dec 26];12(02). Available from: http://jurnal.poltekkespalu.ac.id/index.php/JIK/article/view/104

10. Solihin P. IImu Gizi Klinis pada Anak. 4th ed. Jakarta: Fakultas Kedokteran Universitas Indonesia; 2005.

11. Suraatmaja. Aspek Gizi ASI, ASI Petunjuk untuk Tenaga Kesehatan. Jakarta: EGC; 2001.

12. Moore ER, Coty M-B. Prenatal and Postpartum Focus Groups With Primiparas: Breastfeeding Attitudes, Support, Barriers, Self-efficacy, and Intention. J Pediatr Health Care [Internet]. 2006 Jan [cited 2019 Dec 25];20(1):35-46. Available from: https://linkinghub.elsevier.com/retrieve/pii/S0891524505002981 
13. Suradi R, Tobing HK. Bahan Bacaan: Manajemen Laktasi. 2nd ed. Jakarta: Perkumpulan Perinatologi Indonesia; 2004.

14. Roesli U. Mengenal ASI Eksklusif. Jakarta: Trubus Agriwidya; 2000.

15. Ikatan Dokter Anak Indonesia. Sukses Menyusui Saat Bekerja [Internet]. IDAI. [cited 2019 Dec 26]. Available from: http://www.idai.or.id/artikel/klinik/asi/sukses-menyusuisaat-bekerja-2

16. Lovelady CA, Lonnerdal B, Dewey KG. Lactation Performance of Exercising Women. Am J Clin Nutr [Internet]. 1990 Jul 1 [cited 2019 Dec 25];52(1):103-9. Available from: https://academic.oup.com/ajcn/article/52/1/103/4695395 